\title{
THE EFFORTS TO INCREASE TEXT RECOUNT WRITING BY USING FLOW SENTENCE TECHNIQUES SEMESTER III OF ABA BALIKPAPAN
}

\author{
Muhammad Rochman \\ Akademi Bahasa Asing Balikpapan \\ muhammad_rochman@yahoo.com
}

\begin{abstract}
The background of this research is based on the fact that learning outcomes of the the written recount text is still not as expected. Therefore there needs to be an effort from the lecturer to improve the learning outcomes. This research generally aims to improve students' recount text writing skills. Specifically, this research aims for: 1) Obtaining information about whether or not the flow sentence technique can improve recount text writing skills, 2) Obtain information about the ability of sentence techniques flow increases student participation in learning to write recount texts. Procedure This Classroom Action Research includes stages: (1) action planning (2) implementation actions, (3) observation and interpretation, and (4) analysis and reflection. This research was designed in two cycles using flow sentence techniques. The research instrument uses test and observation techniques. Data analysis techniques use Descriptive analysis, i.e. student learning outcomes were analyzed by describing inter-test scores cycle with performance indicators. Observation results were analyzed descriptively based on results observation and reflection. The results of this Classroom Action Research are: initial conditions 15 students or $46 \%$ are incomplete, 17 students or $54 \%$ complete. In cycle I 8 students or $25 \%$ are incomplete, 24 students or $75 \%$ complete. In Cycle II 4 students or $12.5 \%$ did not complete, 28 students or $87.5 \%$ complete. The results of the study concluded that the use of the technique flowing sentences can improve students' recount text writing skills third semester academic year 2019/2020 of ABA Balikpapan. Flowing sentence techniques can also increase student participation in learning to write recount texts. With a classical completeness level of $87.5 \%$ in the second cycle show that the learning improvement effort has been successful. The sentence technique is effective used to improve recount text writing skills.
\end{abstract}

Keywords: Flow sentence techniques, writing skills

CPendidikan Bahasa Inggris FPISH IKIP BU Malang

\section{Introduction}

Language text writing skills English is one of those skills must be mastered by students. Writing skills good english texts constitute one indication of the success of learning English in general, because with English text writing skills good means students are able use language as a communication tool in writing.

But reality shows that student skills in writing texts recount using English still

not in line with expectations. This can be seen from the results of writing the recount text test student. The average value of the test writing test class third semester recount is 68.87 . Of 32 only 17 students or $54 \%$ complete limit of Mininal Completeness Criteria that has been determined school which is 76 . Number of students that has not been completed as many as 15 students or 46 $\%$ of students. Classical completeness has just reached $54 \%$.

One of the influencing factors the low student learning outcomes are lacking precisely which learning method applied by the teacher in delivering material in class.

Learning methods are used so far is the lecture method, so the students just keep quiet listen to lectures from the teacher and noting material delivered by the teacher. Lecturer more focused on 
explaining various theories writing and examples of recount text and give less opportunities to students to develop the potential to practice writing. In such conditions students will sink deeper into passivity, so students are less challenged to

actively involved in the learning process teach. As a result skills write low recount text.

Based on the description then Researcher propose the use of techniques learning that further increases interest and student participation in learning writing. A text consists of paragraphs logically arranged text and systematic. There are several learning techniques write paragraphs. One of them is technique flowing sentences. Suyatno (2010: 55) explain that learning technique flowing sentences give an idea good paragraph to students through string of sentences produced by individual group members. Students make paragraphs in groups between members.

Based on the background of the problem which has been described above is the formula The problem in this research is as following: 1) Do the use of techniques flowing sentences improve skills write student recount text? 2) Do Use of flowing sentence techniques increase student participation in learning to write recount texts.

In general, this research aims to improve writing skills recount text and increase participation students in the learning process. As for specifically this study aims to obtain information about: 1) Can whether or not the use of flow sentence techniques improve text writing skills recount students 2) Whether or not to use sentence flow techniques improve student participation in learning write recount text.

The benefits of this research are as follows: Benefits for lecturers 1) This research is expected to be used as a reference for information to improve students' recount text writing skills. 2) The lecturer will have knowledge and experience about various techniques learning to write. Benefits for students 1) Students will be motivated to increasingly practice writing text a lot. 2) Students get happy with the technique learning that has never been used by lecturers in learning

writing skills. Benefits for campus can help improve learning English especially writing texts recount.

\section{Research Method}

This research was conducted with Class Action Research approach (Class Action Research) which consists of 2 cycles. Classroom Action Research is research conducted by lecturer in the classroom or the school where he teaches aims to perfect activities learning. As for the steps

CAR implementation is carried out in research this through four stages, namely: (1) action planning (2) implementation actions, (3) observation and interpretation, and (4) analysis and reflection.

Data validation for this study the validity test will be used to check the validity data is triangulation, i.e. with utilizing something else outside the data it is for checking or as purposes comparison of that data. On research this, researchers used data triangulation techniques and triangulation of methods. Data triangulation means the researcher obtained data from various sources in this case lecturer frien, peer language and English instructor.

The technique used for analyze the data that has been obtained between others use statistical techniques comparative recount and critical analysis techniques. This technique is used to analyze quantitative data by comparing inter cycle results. Researchers compared the average score of writing ability on 
conditions before action, after action cycle I, after cycle II and thereafter before research with every final result cycle.

In this study researchers set performance indicators as follows:

1) Students who score $\geq 76$ more of 85\%. 2) Average ability scores Student writing increased from 69 to 76 .

\section{Result and Discussion}

Initial Condition Description Level of student participation in learning to write recount texts on a cycle I: 18 students or $56 \%$ have levels low participation, 8 students or $25 \%$ has a moderate level of participation, 6 students or $19 \%$ have a participation rate high.

After the test, there were 32 students, 17 students who have reached the Criteria limit Minimum Oversight that has been set. 15 students have not reached the limit Criteria limit Minimum Oversight. The average test in the initial condition is

68.87. The highest score is 81 and the lowest score is 47 Classical completeness has only reached $53.87 \%$. This encourages the lecturer to hold actions to improve skills write recount text.

The descrition of Cycle I will be discussed as follow. Cycle I consisted of 3 meetings. Every the meeting was held for $2 \times 40$ minutes. Level of student participation in learning to write recount texts on a cycle

I: 10 students or $32 \%$ have levels low participation, 7 students or $21 \%$ has a moderate level of participation, 15 students or $47 \%$ have levels high participation,

Based on the results of data calculations in the first cycle can be seen that of 32 students there are 24 students or $75 \%$ of them has reached the Completion Criteria limit Minimum that has been determined, while 8 students or 25\% have not reached the limit Minimal completeness criteria. Average results Recount text writing skills test 73.65 . The highest score is 85 and the lowest score is $49.75 \%$ classical completeness.

The description of Cycle II will be discussed as follow. Cycle II consists of 3 meetings. Each meeting is held for $2 \times 40$ minute. Level of student participation in learning to write recount texts on a cycle II: 4 students or $12 \%$ have levels low participation, 5 students or $16 \%$ has a moderate level of participation, 23 students or $72 \%$ have a participation rate high.

Based on the results of data calculations after the cycle 2 action can be it is known that from 32 students there were 28 students or $87.5 \%$ who have reached the Criteria limit Minimum completeness predetermined, while 4 students or $12.5 \%$ have not reached the Minimum completeness Criteria limit. Average text writing skills test results recount 76.65 . The highest score is 89 and the score lowest 60. Classical completeness $75 \%$.

\section{Conclusion}

Based on the results of data processing from improved learning that has been implemented it can be concluded that Learning with flowing sentence techniques can improve writing skills recount text and student participation in learning to write recount texts.

With the research carried out this class action, then it can be submitted implications as follows 1) Application of the technique flowing sentences are expected to have a positive impact on learning progress in English language skills to be develoved by students especially in the aspect of writing texts recount in ABA Balikpapan especially in terms of applying models varied learning. 2) Implementation Flowing sentence techniques can be used as an alternative learning to increase participation and recount text writing skills. 
References

Suprijono, A. (2009). Cooperative Learning Teori dan Aplikasi Paikem. Yogjakarta: Pustaka Pelajar.

Lie, A. (2002). Mempraktikkan Coopertive Learning di RuangRuang Kelas.

Jakarta : Gramedia.

Arnie F., dkk. (2005). Portofolio dalam pembelajaran IPS. Bandung : PT Remaja Rosdakarya

Fahrudin, A. (2011). Menjadi guru favorite. Jogyakarta : Diva Press

Bachtiar, B., dkk, (2005). Let's Talk, Pakar Raya. Bandung.

Chaedar, A. (1997). Politik Bahasa dan Pendidikan. Bandung: PT Remaja Rosdakarya

Dutton, J. (2019). Writing Paragraphs

That Flow. Retrieved from internet at https://www.e-

education.psu.edu/styleforstudents/c1_p

$\underline{\text { 3.html }}$

Hamzah B. (2008). Model Pembelajaran

Menciptakan proses Belajar

Mengajar Yang Kreatif dan Efektif.

Jakarta: Bumi Aksara

Tarigan, H. (1990). Pengajaran kompetensi Bahasa. Bandung: Angkasa

Usman, M. (2011). Menjadi Guru Profesional. Bandung : PT Remaja Rosdakarya

Purdy, J. (2009). Creating Flow: Sentences A writing wo rkshop presented by BACTER
(Bringing Advanced Computa\&on al Techniques to Energy Research) University of Wisconsin-Madison. October 2009.

Sabarti, A., dkk. (2001). Menulis I. Buku Materi Pokok. Jakarta: Pusat Penerbitan

Universitas Terbuka.

Slameto. (1995). Belajar dan FaktorFaktor yang Mempengaruhinya. Jakarta : PT

Rineka Cipta.

Arikunto, S.,dkk. (2007). Penelitian Tindakan Kelas. Jakarta : PT Dumi Aksara.

Suyatno. (2010). Teknik Pembelajaran Bahasa dan Sastra, Surabaya : SIC 